\title{
Primary cutaneous centrofollicular lymphoma with a good response to radiotherapy*
}

\section{Linfoma centrofolicular cutâneo primário com boa resposta a radioterapia}

\author{
Cláudia Medeiros dos Santos Camargo ${ }^{1}$ \\ Leonardo Spagnol Abraham ${ }^{3}$ \\ Maria de Fátima Guimarães Scotelaro ${ }^{5}$
}

\author{
Lislaine Bomm² \\ Rafael Daher ${ }^{4}$ \\ Luna Azulay Abulafia ${ }^{6}$
}

\begin{abstract}
Primary cutaneous lymphomas have different clinical behavior and prognosis than systemic lymphomas of similar histological subtype. About 30\% of non-Hodgkin lymphomas involve extranodal tissues, the skin being the second most affected body organ after the gastrointestinal tract (approximately 18\%). According to the EORTC (European Organization for Research and Treatment of Cancer) classification, the lymphoma centrofollicular is indolent, since the lesions increase in size slowly over the years and spread to extracutaneous sites is uncommon. Based on this, radiotherapy has been considered the treatment of choice by many studies. We present the case of a patient who had cutaneous centrofollicular scalp lymphoma for 1 year and showed good response to radiotherapy.
\end{abstract}

Keywords: B-Lymphocytes; Lymphoma; Lymphoma, B-cell; Lymphoma, follicular; Radiotherapy

Resumo: Os linfomas cutâneos primários têm comportamento clínico e prognóstico diferente dos linfomas sistêmicos de subtipo histológico semelhante. Cerca de 30\% dos linfomas não-Hodgkin acometem tecidos extranodais, sendo a pele o segundo órgão mais envolvido após o trato gastrointestinal (aproximadamente 18\%). De acordo com a classificação EORTC (European Organization for Research and Treatment of Cancer), o linfoma centrofolicular cutâneo é indolente, uma vez que as lesões aumentam de tamanho lentamente ao longo dos anos e a disseminação para sitios extracutâneos é incomum. Com base nisso, a radioterapia tem sido apontada como o tratamento de primeira escolha por muitos estudos. Apresentamos um caso de paciente com linfoma cutâneo centrofolicular no couro cabeludo há 1 ano e que apresentou boa resposta à radioterapia.

Palavras-chave: Linfoma; Linfoma folicular; Linfoma de células B; Linfócitos B; Radioterapia

\section{INTRODUCTION}

Primary cutaneous lymphomas frequently have clinical behavior and prognosis different than systemic lymphomas of similar histological subtype. About $30 \%$ of the non-Hodgkin lymphomas affect extranodal tissues, the skin being the second most affected organ after the gastrointestinal tract, or around $18 \%$ of all lymphomas. ${ }^{1}$ According to the EORTC classification (Cutaneous Lymphoma Study Group of the European Organization for Research and Received on 09.01.2013.

Approved by the Advisory Board and accepted for publication on 29.01.2013.

* Work carried out at the Pedro Ernesto University Hospital - State University of Rio de Janeiro (HUPE-UERJ) - Rio de Janeiro (RJ), Brazil.

Conflict of interest: None

Financial funding: None

MD - Graduate student in Dermatology at Hospital Universitário Pedro Ernesto - Universidade do Estado do Rio de Janeiro (HUPE-UERJ) - Rio de Janeiro (RJ), Brazil.

Dermatologist - Private Clinic - Rio de Janeiro (RJ), Brazil.

MD, Master's Degree program student - Volunteer dermatologist at Hospital Universitário de Brasília - Universidade de Brasília (HUB-UnB) - Brasília (DF), Brazil.

MD, Radiotherapist in charge of the Radiotherapy Service at Hospital Universitário Pedro Ernesto - Universidade do Estado do Rio de Janeiro (HUPE-UERJ) - Rio de Janeiro (RJ), Brazil.

MD, PhD - Professor at the Dermatopathology Department of Hospital Universitário Pedro Ernesto - Universidade do Estado do Rio de Janeiro (HUPE-UERJ) - Rio de Janeiro (RJ), Brazil.

MD, PhD - Professor at the Dermatology Department of Hospital Universitário Pedro Ernesto - Universidade do Estado do Rio de Janeiro (HUPE-UERJ) Rio de Janeiro (RJ), Brazil.
Treatment of Cancer), the cutaneous centrofollicular lymphoma is a B-cell indolent lymphoma, since the lesions grow slowly in size over the years and dissemination to extracutaneous sites is uncommon. ${ }^{2}$ With that in mind, radiotherapy has been referred as the first-choice treatment by many studies. ${ }^{3,4}$ The case of a patient with cutaneous centrofollicular lymphoma on the scalp with one year of evolution is presented, which showed good response to radiotherapy. 


\section{CASE REPORT}

A 45 year-old white male, previously healthy, presented infiltrated plaques and coalescent nodules on the left parietal region one year ago. He reported history of local trauma six months before the onset of the lesion. He denied local or systemic symptomatology (fever, night sweat or weight loss). On the dermatological exam were found plaques and erythematous nodules of hard consistency, measuring about $8 \times 4 \mathrm{~cm}$ (Figure 1). Palpable lymphadenopathy was absent. The histopathological exam demonstrated a large diffuse dermal infiltrate that spared the epidermis, with a partial follicular component (Figure 2). The infiltrate was composed of a population of central follicle cells, predominantly with multilobed nuclei, associated with large centroblasts and mixed centrocytes and surrounded by a great quantity of small reactive $\mathrm{T}$ lymphocytes (Figures 3 and 4).

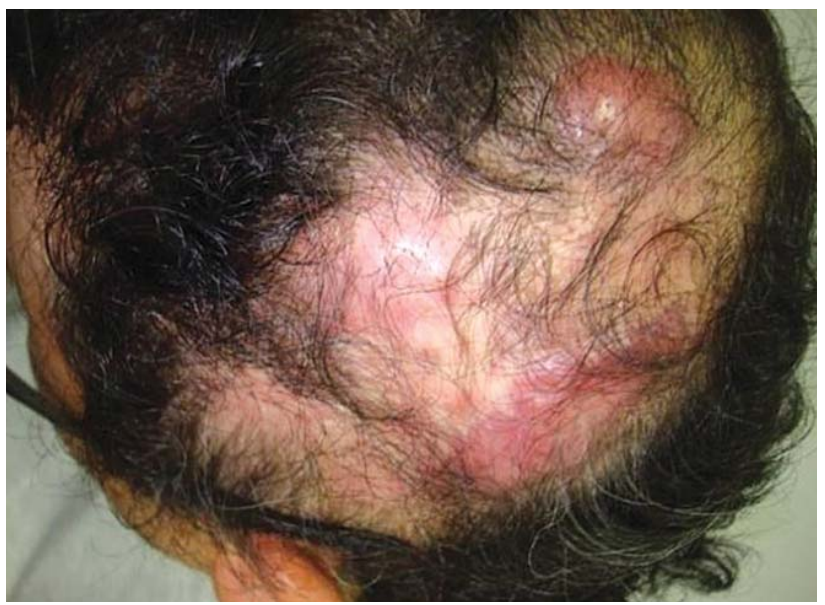

Figure 1:Erythematous Plaques and nodes, of hard consistency, measuring about $8 \times 4 \mathrm{~cm}$

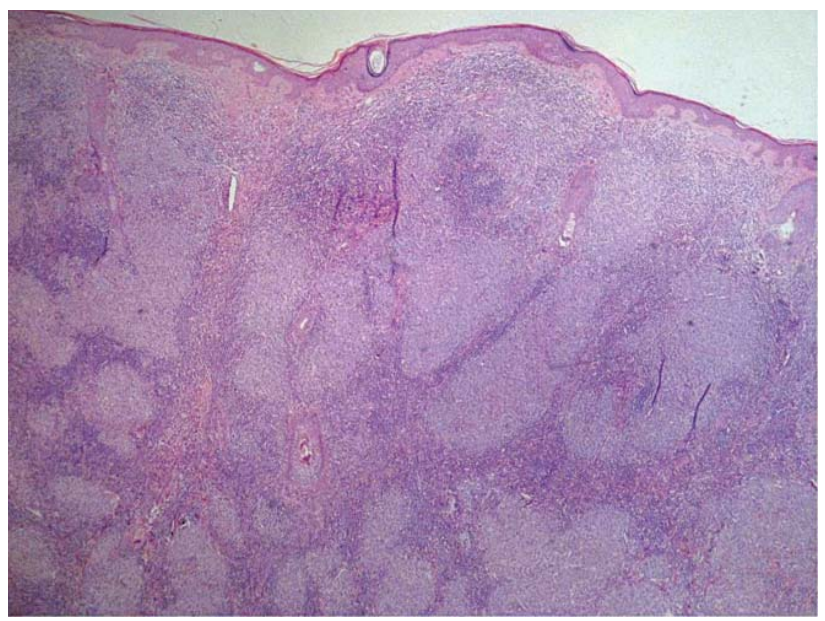

FIGURE 2:Large diffuse dermal infiltrate that spared the epidermis, with a partial follicular component

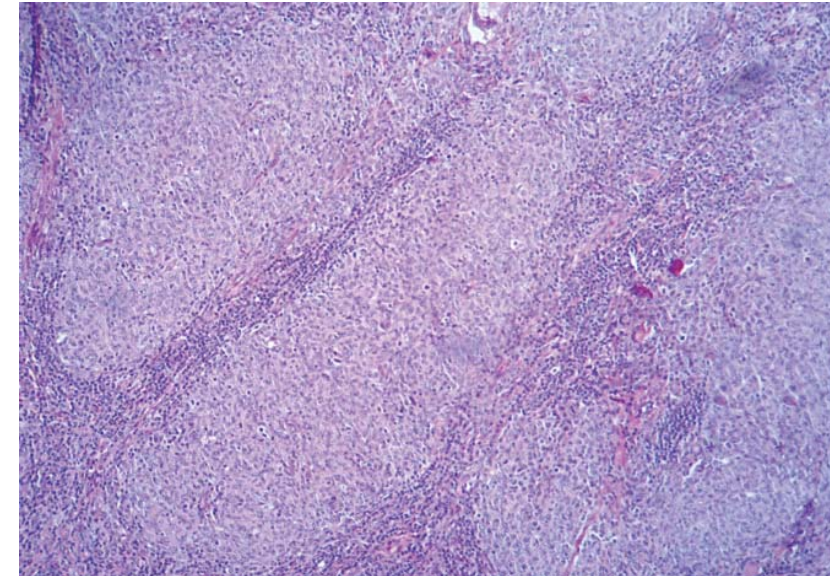

FIGURE 3:Multilobed nuclei, associated with large centroblasts and centrocytes

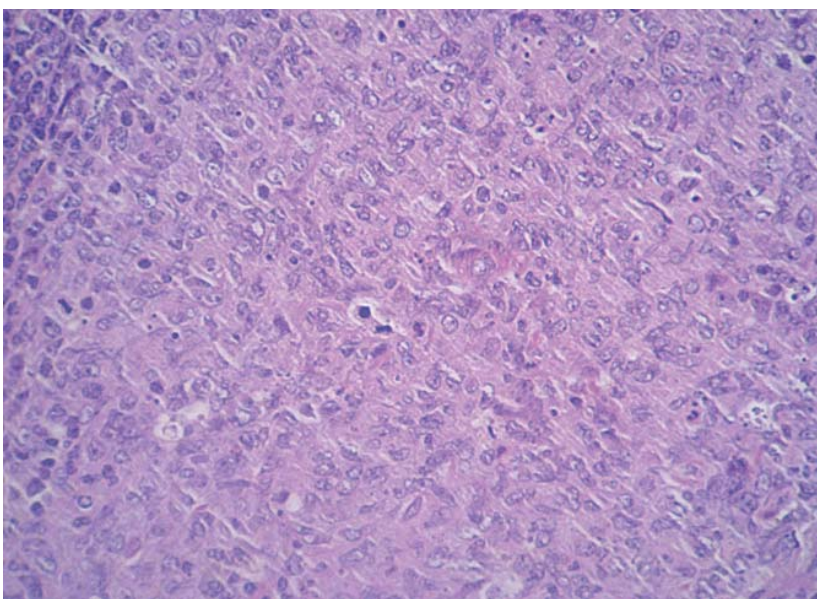

FIGURE 4:Dermal infiltrate in higher magnification (100X)

Immunohistochemistry was positive for CD5 and CD20 and negative for CD30. After the centrofollicular lymphoma diagnosis, the patient was referred for hematologic evaluation for research on systemic disease, which was negative; the classification was TNM TxNOM0. He was submitted to radiotherapy with 3,060 cGy in 17 fractions on the scalp lesion, with the $9 \mathrm{MeV}$ direct electronic fields technique for 25 days, with good local response.

\section{DISCUSSION}

The cutaneous B-cell lymphomas represent 25\% of cutaneous lymphomas. By the new WHO-EORTC classification, these are divided into primary cutaneous centrofollicular lymphoma, primary cutaneous marginal zone lymphoma and primary cutaneous large cell lymphoma leg type. ${ }^{1,2}$ The primary cutaneous 
centrofollicular lymphoma is a relatively common lymphoma, characterized by the neoplastic proliferation of centrocytes and centroblasts confined to the skin. The survival rate for this kind of lymphoma is $95 \%$ in 5 years, its prognosis being very favorable with low probability of extracutaneous dissemination., ${ }^{3,4}$ Clinically, they present as plaques or nodes, solitary or grouped, being either normochromic or erythematous. Their favorite sites are the head (front and scalp) and dorsum. Recurrences are observed in about $50 \%$ of the cases, but dissemination to internal organs is rare. ${ }^{3}$ The histological exam is characterized by a pattern of diffuse and/or follicular growth findings, composed of a

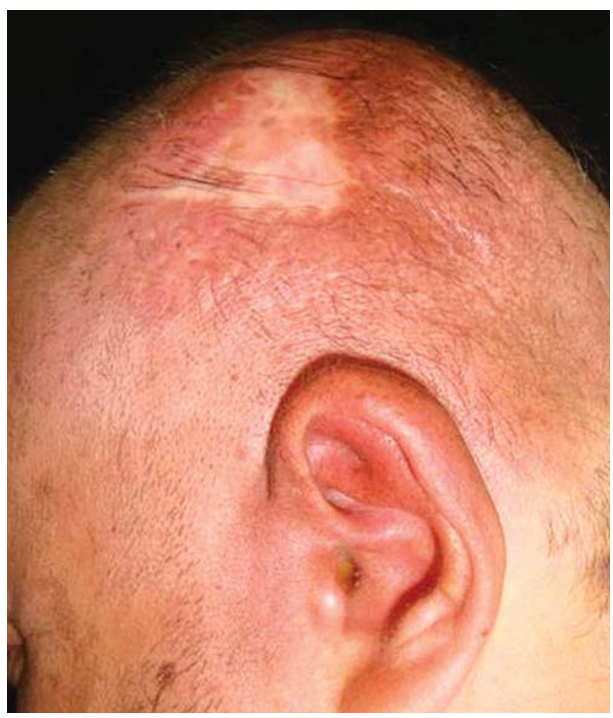

FIGURE 5: Complete resolution of cutaneous lesion, presenting only cicatricial alopecia plaque on the site variable mix of small and/or big neoplastic cleaved cells (centroblasts), aside from immunoblasts, small lymphocytes, histiocytes, eosinophils and plasma cells. Sometimes there may be reactive lymphoid follicles resembling germinal centers, which, many times, hinders the differential diagnosis with pseudo lymphomas. ${ }^{1,2}$ The immunohistochemistry of tumor cells reveals CD20, CD79a, CD10 and bcl-6 neoplastic cells masked as positive. Markers for CD5, CD43 and bcl-2 are rarely positive. Since the cutaneous metastases of nodal follicular lymphoma strongly express bcl-2 and CD10 proteins, the differential diagnosis can be done between these and the primary cutaneous lymphomas. ${ }^{5,6}$ Lymphomas are neoplasms that are very sensitive to ionizing radiation. Lymphoma sensitivity is usually greater than that of the local surrounding tissue, which makes them very different from other solid neoplasms. ${ }^{6,7}$ There is little data about the doseresponse of radiotherapy for non-Hodgkin lymphomas. Studies demonstrate that for the cutaneous centrofollicular lymphoma radiotherapy is the firstline treatment of choice. The 25-35Gy dose is able to control the disease more than $90 \%$, the radiation field being a little larger than the tumor so that non-visible lesions are also treated. ${ }^{7}$ Other treatments indicated are surgical excision of small lesions; for too extensive cutaneous lesions and extracutaneous disease, chemotherapy is indicated. The therapeutic efficiency of anti-CD20 antibody, intralesional or systemic, has recently been demonstrated. ${ }^{6,7}$ Our patient presented excellent response to radiotherapy, with complete resolution of the cutaneous lesion, presenting only an alopecia plaque on the lesion's site (Figure 5). $\square$

\section{REFERENCES}

1. Moricz CZM, Sanches JR JA. Processos linfoproliferativos da pele. Parte -1 Linfomas cutâneos de células B. An Bras Dermatol. 2005;80:461-71.

2. Senff NJ, Noordijk EM, Kim YH, Bagot M, Berti E, Cerroni L, et al. European Organization for Research and Treatment of Cancer and International Society for Cutaneous Lymphoma consensus recommendations for the management of cutaneous B-cell lymphomas. Blood. 2008;112:1600-9.

3. Smith BD, Glusac EJ, McNiff JM, Smith GL, Heald PW, Cooper DL, et al. Primary Cutaneous B-Cell Lymphoma Treated With Radiotherapy: A Comparison of the European Organization for Research and Treatment of Cancer and the WHO Classification Systems. J Clin Oncol. 2004; 22:634-9.

4. Pandolfino TL, Siegel RS, Kuzel TM, Rosen ST, Guitart J. Primary cutaneous B-cell lymphoma: Review and current concepts. J Clin Oncol. 2000;18:2152-68.

5. Bergman R. Pseudolymphoma and cutaneous lymphoma: facts and controversies. Clin Dermatol. 2010;28:568-74

6. Kirova YM, Piedbois Y, Le Bourgeois JP. Radiotherapy in the management of cutaneous B-cell lymphoma: Our experience in 25 cases. Radiother Oncol. 1999:52:15-8.

7. Halperin EC, Perez CA, Brady LW, Wazer DE, Freeman C. Prosnitz LR. Principles and Practice of Radiation Oncology. 5th. ed. Philadelphia: Lippincott Williams \& Wilkins 2007. p.1748-76.

\author{
MAILING ADDRESS: \\ Cláudia Medeiros dos Santos Camargo \\ Avenida 28 de Setembro, 77 -Vila isabel \\ 20551-080 - Rio de Janeiro - RJ \\ Brazil \\ E-mail: mdsc.claudia@gmail.com
}

How to cite this article: Camargo CMS, Bomm L, Abraham LS, Daher R, Scotelaro MFGA, Azulay Abulafia L. Primary cutaneous lymphoma centrofolicular with a good response to radiotherapy. An Bras Dermatol. 2013;88(6 Suppl 1):S136-8. 